\title{
Policy, Plain Language, and Legislative Purpose: ApPlying State Medical Malpractice Caps ON DAMAges TO Federal EMTALA ClaIMS
}

\author{
Lauren N. Grattenthaler
}

\section{TABLE OF CONTENTS}

I. INTRODUCTION 86

II. THE STATUTORY LANDSCAPE: ANALYTICAL FRAMEWORK AND REQUIREMENTS OF EMTALA AND STATE MEDICAL MALPRACTICE DAMAGE CAPS

A. Interpreting EMTALA: The General Statutory Requirements and the Courts' Struggle to Clarify the Damages Provision

B. The Medical Liability Crisis and Tort Reform: A General Framework of State Medical Malpractice Statutes and the Effects of Damage Caps

III. ARGUMENTS FOR AND AGAINST APPLYING STATE

MEDICAL MALPRACTICE DAMAGE CAPS TO EMTALA ..................95

A. The Minority View: Unlimited Damages Through

Failing to Apply State Damage Caps to EMTALA Claims.........95

1. Virginia: Power v. Arlington Hospital Ass'n I ....................96

2. Florida: Cooper v. Gulf Breeze Hospital, Inc. ....................98

3. California: Jackson v. East Bay Hospital .............................98

B. The Majority View: Limiting Damages By Applying

State Damage Caps to EMTALA Claims.....................................99

1. The Sixth Circuit: Smith v. Botsford General Hospital........99

2. The Fourth Circuit: Power v. Arlington Hospital Ass' $n$ II

IV. PROMOTING ACCESSIBLE, AFFORDABLE, AND HIGH

QUALITY HEALTH CARE: KEY POLICY REASONS FOR

APPLYING STATE MEDICAL MALPRACTICE DAMAGE CAPS

TO EMTALA CLAIMS

A. Incorporating Damage Caps Will Prevent Plaintiffs from Circumventing State Damage Caps by Bringing Their State Malpractice Claims in Federal Court

* J.D. Candidate, 2007, Indiana University School of Law, Indianapolis, Indiana; B.A., 2004, Indiana University, Bloomington, Indiana. I would like to thank my family for their invaluable guidance, patience, and support, especially my mother, Robyn, and my sisters, Jaime and Erin. 
Under EMTALA

B. Incorporating Damage Caps Will Prevent

Forum Shopping

C. Incorporating Damage Caps Furthers the Purposes of EMTALA and State Medical Malpractice Statutes.

V. CONCLUSION 112

\section{INTRODUCTION}

In response to concerns regarding the "dumping" of uninsured and indigent patients by hospitals, Congress enacted the Emergency Medical Treatment and Active Labor Act ("EMTALA") 1 as part of the Consolidated Omnibus Budget Reconciliation Act ("COBRA") of $1985^{2}{ }^{3}$. Several studies conducted prior to the enactment of EMTALA estimated that emergency facilities dumped at least 250,000 patients each year ${ }^{4}$ and that eighty-seven percent of hospitals transferred patients for solely economic reasons. ${ }^{5}$ Congress's primary purpose behind the enactment of EMTALA was to prevent hospitals from refusing to treat indigent patients in emergency situations because of their inability to pay. In addition, EMTALA was designed to curtail the transfer of indigent and uninsured patients by private hospitals to non-profit hospitals before life-threatening conditions had been stabilized. ${ }^{6}$ Ultimately, the goal of EMTALA was to ensure that every person had adequate access to emergency health care, especially the uninsured and indigent. ${ }^{7}$

To further this goal of ready access to health care, many states have enacted medical malpractice statutes over the past few decades as part of a general

\footnotetext{
1 Emergency Medical Treatment and Active Labor Act (EMTALA), 42 U.S.C. $\S$ 1395dd (2000).

${ }^{2}$ Consolidated Omnibus Budget Reconciliation Act of 1985, Pub. L. No. 99-272, § 9121, 100 Stat. 82, 164-65 (1986).

${ }^{3}$ Leigh M. Chiles, Case Note, Summers v. Baptist Medical Center Arkadelphia: $A$ "Disparate" Application of EMTALA's Terms, 50 ARK. L. REV. 559, 559 (1997).

4 Wendy W. Bera, Comment, Preventing "Patient-Dumping": The Supreme Court Turns Away the Sixth Circuit's Interpretation of EMTALA, 36 Hous. L. REv. 615, 619 \& n.19 (1999) (citing David A. Hyman, Lies, Damned Lies, and Narrative, 73 IND. L.J. 797, 863 n.330 (1998) (arguing this estimate is misleading, however, because it is based on a skewed sample of large urban cities with a substantial number of indigent and uninsured individuals and an overly broad definition of "dumping")).

${ }^{5}$ Id. at 619 \& n.20 (citing Robert L. Schiff et al., Transfers to a Public Hospital: [A Prospective Study of 467 Patients], 314 NEw ENG. J. MED. 552, 556 (1986)).

${ }^{6}$ Chiles, supra note 3.

7 Bryant v. Adventist Health Sys., 289 F.3d 1162, 1169-70 (9th Cir. 2002); see also Bera, supra note 4, at 620 .
} 
tort reform movement sweeping across the country. ${ }^{8}$ These malpractice statutes often include some form of a damage cap, as well as medical review panel requirements, a statute of limitations, and prescribed amounts of malpractice insurance coverage. ${ }^{9}$ While tort reform has been effective in many states in the context of medical malpractice, medical liability reform remains a primary focus of state medical associations' and the American Medical Association's ("AMA") advocacy efforts to reduce medical liability premiums at the federal and state levels and ultimately, to improve quality and access to health care. ${ }^{10}$

The initial call to state legislatures and Congress for relief from the declared malpractice crisis occurring in many states was prompted by dramatic increases in medical malpractice insurance premiums. ${ }^{11}$ These increases were a primary result of the high frequency of claims filed against health care profes-

8 See generally AM. TORT REFORM ASS'N, TORT REFORM RECORD (2005), available at http://www.atra.org/files.cgi/7990_Record_12-31-05.pdf (providing a state-by-state summary of tort reforms enacted since 1986).

9 See, e.g., IND. CODE $\S \S 34-18-1$ to -18 (2004). In a recent unanimous opinion, Ledbetter $v$. Hunter, the Indiana Supreme Court affirmed the constitutionality of the Indiana Medical Malpractice Act's statute of limitations for minors, reversing the Indiana Court of Appeals' opinion. Ledbetter v. Hunter, 842 N.E.2d 810, 815 (Ind. 2006), rev'g 810 N.E.2d 1095, 1103 (Ind. Ct. App. 2004) (holding that the statute of limitations for minors violated the Privileges and Immunities Clause of the Indiana Constitution). Ledbetter restored the time period in which a minor may file a malpractice claim back to the original statute of limitations, which is two years or until age eight if injured before age six. Id.

By upholding the original statute of limitations for minors, the court narrowed the window of time in which claims can be filed, thus preventing an additional flood of claims and a consequent adverse effect on medical malpractice insurance premiums. Indiana Supreme Court Upholds Statute of Limitations for Minors, ISMA REPORTS (Indiana State Medical Association, Indianapolis, Indiana), Mar. 6, 2006, at 1. Therefore, the court's decision is consistent with the policies underlying medical malpractice statutes of ensuring a high quality of and access to health care. In addition, this decision emphasizes that a plaintiff must have a strong showing to overcome the presumption of constitutionality applied to Indiana's medical malpractice statute. Id.

10 The AMA continues to lobby Congress for malpractice liability reforms, such as a $\$ 250,000$ cap on non-economic damages in medical liability cases. AMA Medical Liability Reform, http://www.ama-assn.org/ama/pub/category/7861.html.

${ }_{11}$ In 2002, physicians' malpractice insurance rates across the country increased approximately twenty percent on average. Richard E. Anderson, Effective Legal Reform and the Malpractice Insurance Crisis, 5 YALE J. HeAlTH POL'Y L. \& ETHICS 341, 344 \& n.9 (2005) [hereinafter Anderson, Effective Legal Reform] (citing 2002 Rate Survey Finds Malpractice Premiums Are Soaring ..., MED. LIABILITY MONITOR, Oct. 2002, at I-IV). However, states that have enacted effective malpractice legal reforms, such as California and Indiana, have seen insurance rates grow by only a few percentage points per year during this same time period and enjoy some of the lowest rates in the country. Id.; see also Richard E. Anderson, Defending the Practice of Medicine, 164 ARCHIVES OF INTERNAL MED. 1173, 1174 (2004) [hereinafter Anderson, Defending the Practice] (discussing the decrease in several states' insurance premium rates as a result of malpractice reforms). Conversely, states without effective reforms have experienced increases in excess of one hundred percent for physicians in high-risk medical specialties. Anderson, Effective Legal Reform, supra, at 345. 
sionals and the potentially unlimited, excessive verdicts being awarded to plaintiffs in malpractice suits. ${ }^{12}$ To date, the AMA has recognized twenty-one states that are currently in a state of medical malpractice liability crisis, an increase from twelve in 2002. ${ }^{13}$ Because of the drastic premium rate increases, some physicians have been rendered virtually uninsurable at any price and have been forced to resort to state-run plans, ${ }^{14}$ which are even more expensive than coverage in the insurance market, in order to continue practicing medicine. ${ }^{15}$

Since the enactment of EMTALA and the emergence of medical malpractice reform as a primary issue on legislative agendas, courts have struggled to draw a clear distinction between EMTALA liability and traditional medical malpractice liability. ${ }^{16}$ This is due, in part, to the similarities in the nature of the conduct often at issue in both EMTALA and state medical malpractice claims. Frequently, in an EMTALA case, there is an underlying issue of possible medical negligence or substandard care; however, EMTALA does not create a cause of action on the basis of that type of conduct or theory. ${ }^{17}$ In addition, while courts generally agree that EMTALA does not create a federal cause of action for medical malpractice, ${ }^{18}$ courts still disagree as to whether

12 See Anderson, Effective Legal Reform, supra note 11, at 344.

13 AM. MED. Ass'N, AMERICA's MEdiCAL LIABILITY CRISIS: A National VIEW (2007), available at $\mathrm{http}: / / \mathrm{www}$. ama-assn.org/ama/noindex/category/1 1871.html [hereinafter MEDICAL LIABILITY CRISIS MAP] (providing a map denoting "crisis," "caution," and "stable" states).

14 An example of such a plan is Indiana's state insurance program, which provides that health care providers who are declined coverage by at least two insurers may apply for malpractice liability insurance through the Indiana Residual Malpractice Insurance Authority ("IRMIA"). IND. CODE § 34-18-17-6 (2004).

15 Anderson, Effective Legal Reform, supra note 11, at 345.

16 Chiles, supra note 3, at 560 .

17 See infra note 18 and accompanying text.

18 See, e.g., Bryant v. Adventist Health Sys., 289 F.3d 1162, 1170 (9th Cir. 2002) (holding that a hospital could not be liable under EMTALA for its staff's failure to detect an emergency medical condition because EMTALA's purpose was to address the failure of hospitals to provide emergency medical care to the uninsured and indigent and was not intended to be a federal malpractice statute); Correa v. Hosp. San Francisco, 69 F.3d 1184, 1192 (1st Cir. 1995) ("EMTALA does not create a cause of action for medical malpractice."); Eberhardt v. City of Los Angeles, 62 F.3d 1253, 1258 (9th Cir. 1995); Repp v. Anadarko Mun. Hosp., 43 F.3d 519, 522 (10th Cir. 1994); Holcomb v. Monahan, 30 F.3d 116, 117 (11th Cir. 1994). Thus, although a failure to follow regular screening procedures may violate EMTALA, a faulty screening, "as opposed to disparate screening or refusing to screen at all," does not. Correa, 69 F.3d at 1192 93.

Furthermore, courts have maintained that a claim alleging misdiagnosis or inadequate treatment is a matter of state malpractice law. See Vickers v. Nash Gen. Hosp., Inc., 78 F.3d 139, 142-43 (4th Cir. 1996); Summers v. Baptist Med. Ctr. Arkadelphia, 91 F.3d 1132, 1137 (8th Cir. 1996); Williams v. Birkeness, 34 F.3d 695, 697 (8th Cir. 1994) (holding that EMTALA claims do not rest upon proof that a hospital was negligent or that the hospital failed to make a correct diagnosis or provide adequate treatment); Brooks v. Maryland Gen. Hosp., Inc., 996 F.2d 708, 710 (4th Cir. 1993) ("The Act was not designed to provide a federal remedy for misdiagnosis or general malpractice."); Baber v. Hosp. Corp. of Am., 977 F.2d 872, 880 (4th 
federal EMTALA claims are subject to caps on damages provided for in state medical malpractice statutes. ${ }^{19}$ This disagreement stems from the issue of what constitutes "damages available for personal injury" provided for in EMTALA's damages provision ${ }^{20}$, as well as the varying ways in which states define "malpractice." 21 The need for clarification on this issue has been heightened by the flood of EMTALA claims following its enactment, especially considering the potential policy implications and adverse effects that judicial decisions concerning those claims could have on health care in the United States. ${ }^{22}$

This Note asserts the majority position that, although EMTALA is not technically a federal medical malpractice statute, damages applicable to state medical malpractice claims should likewise apply to EMTALA claims.

Part II of this Note will focus on the general background of EMTALA and state medical malpractice statutes, outline the main provisions of EMTALA, and discuss the structure and mechanics of typical state medical malpractice statutes, specifically, the damage cap provisions. Part III will examine the arguments for and against the application of state medical malpractice damage caps to EMTALA claims. In doing so, this section will look at several court decisions in various jurisdictions that have analyzed the language and application of EMTALA's damages provision. Specifically, courts have focused on the issue of whether EMTALA incorporates state medical malpractice caps on damages, thus subjecting EMTALA claim recoveries to those limits. Part IV will discuss and analyze the key policy reasons for incorporating state damage caps into EMTALA. Part V will conclude with a brief summary of the reasons for applying damage caps to EMTALA while focusing on the underlying objectives of both EMTALA and state medical malpractice statutes.

Cir. 1992) ("EMTALA is no substitute for state law medical malpractice actions.").

Rather, EMTALA was intended to create a wholly new cause of action, separate and distinct from traditional state medical malpractice claims. See Gatewood v. Washington Healthcare Corp., 933 F.2d 1037, 1041 (D.C. Cir. 1991) (holding that the plaintiff could not bring a malpractice claim under EMTALA because that would result in a federalization of malpractice claims, which courts have sought to avoid, and would thereby permit virtually any claim of medical malpractice to be brought as an EMTALA action; EMTALA "is not intended to duplicate preexisting legal protections ...."); see also Vickers, $78 \mathrm{~F} .3 \mathrm{~d}$ at 141 . In addition, EMTALA "does not set a national emergency health care standard." Summers, 91 F.3d at 1137.

19 See Chiles, supra note 3, at 560; for an interesting discussion of EMTALA as a federal malpractice statute, see Demetrios G. Metropoulos, Note, Son of COBRA: The Evolution of a Federal Malpractice Law, 45 STAN. L. REV. 263 (1992).

2042 U.S.C $\$ 1395 \mathrm{dd}(\mathrm{d})(2)(\mathrm{A})(2000)$.

${ }^{21}$ See discussion infra Parts III.A.1, B.1-.2.

${ }^{22}$ Chiles, supra note 3, at 560. 


\section{THE STATUTORY LANDSCAPE: ANALYTICAL FRAMEWORK AND REQUIREMENTS OF EMTALA AND STATE MEDICAL MALPRACTICE DAMAGE CAPS}

\section{A. Interpreting EMTALA: The General Statutory Requirements and the Courts' Struggle to Clarify the Damages Provision}

Under common law, a physician does not owe a duty to provide medical treatment. ${ }^{23}$ In addition, hospitals do not owe a duty of care directly to patients because a hospital is not considered to be practicing medicine. ${ }^{24}$ Without EMTALA, hospitals would be able to refuse treatment to anyone, even those patients with life-threatening conditions. ${ }^{25}$ Thus, assuming that most health care providers would not voluntarily treat patients if they knew in advance they would not be compensated, the enactment of EMTALA was necessary to ensure adequate access to emergency health care. ${ }^{26}$

Although EMTALA was enacted in response to concerns that hospitals were dumping patients because of their inability to pay, it applies to all patients who seek emergency treatment, regardless of their ability to pay or insurance status, and is not explicitly limited to indigent patients. ${ }^{27}$ EMTALA requires all

23 E.g., Hurley v. Eddingfield, 59 N.E. 1058, 1058 (Ind. 1901) (holding licensed physician not required to respond to a call), cited in Bera, supra note 4, at 621; Oliver v. Brock, 342 So. 2d 1, 3 (Ala. 1976) (stating physician is under no obligation to accept professional employment); Findlay v. Bd. of Supervisors of Mohave County, 230 P.2d 526, 531 (Ariz. 1951); Childers v. Frye, 158 N.E. 744, 746 (N.C. 1931).

24 E.g., Schloendorff v. Soc'y of New York Hosp., 105 N.E. 92, 93 (N.Y. 1914), cited in Bera, supra note 4, at 623 n.36 (explaining that the hospital is not liable for the negligent actions of physicians in the treatment of patients because physicians act as independent contractors), superseded by statute, N.Y. PUB. HEALTH LAw $\S 2805-d$ (McKinney 2002 \& Supp. 2007) (effective July 1, 1975); Bera, supra note 4, at 623.

25 Bera, supra note 4, at 623.

26 Id. at 621-22. EMTALA has been criticized, however, as contradictory to state tort reform enactments because it gives plaintiffs and their attorneys yet another avenue through which to sue. It also enables plaintiffs to circumvent state damage caps and thus recover greater monetary awards by framing traditional medical malpractice claims as EMTALA claims. See discussion infra Part IV.A. In addition to damage caps, plaintiffs may also be able to avoid other state statutory requirements applicable in medical malpractice cases, such as mandatory arbitration. Id. at 636-37; see generally discussion infra Part IV. In addition, EMTALA has been referred to as an "unfunded mandate that requires hospitals and physicians to provide emergency care without establishing a way to pay for that care." Julia Ai, Note, Does EMTALA Apply to Inpatients Located Anywhere in a Hospital?, 32 RUTGERS L.J. 549, 551 (2001).

27 See Collins v. DePaul Hosp., 963 F.2d 303, 308 (10th Cir. 1992); Gatewood v. Washington Healthcare Corp., 933 F.2d 1037, 1040 (D.C. Cir. 1991) (concluding that the plain language of EMTALA under a strict interpretation of the statute extends protection to all individuals and not just the indigent); Thornton v. Sw. Detroit Hosp., 895 F.2d 1131, 1134 (6th Cir. 1990). Furthermore, the phrase "[i]f any individual ... comes to a hospital ..," 42 U.S.C. $\S 1395 \mathrm{dd}(\mathrm{b})(1)$ (2000), allows EMTALA to be applied in a wide variety of situations. Bera, supra note 4, at 623 . 
hospitals participating in Medicare and Medicaid to provide an "appropriate medical screening examination within the capability of the hospital's emergency department" to every person who comes to the emergency room and requests treatment, in order to determine whether or not an emergency medical condition exists. ${ }^{28}$ If an emergency condition exists, the hospital has a duty to treat and stabilize the condition or transfer the patient if the benefits of transfer outweigh the risks of harm to the patient. ${ }^{29}$ Although hospitals are required to stabilize emergency patients, EMTALA does not require them to perform the impossible. ${ }^{30}$ If a hospital does not have the facilities necessary to fully stabilize a patient, and the patient must be transferred to another hospital to receive the necessary care, the first hospital can transfer the patient to the more sophisticated hospital without violating EMTALA. ${ }^{31}$ The transferring hospital must do all it can to stabilize the patient's condition, but it need not do what it cannot. ${ }^{32}$ Thus, a hospital may violate EMTALA by either failing to provide an appropriate medical screening, or if an emergency condition is found to be present in the initial screening, failing to stabilize or transfer the patient appropriately. ${ }^{33}$

An EMTALA screening obligation is triggered in one of two ways: 1) when an individual presents at a hospital emergency department and requests examination or treatment for a medical condition, ${ }^{34}$ or 2 ) when the individual presents somewhere else on hospital property (but not recognized as part of the emergency department) and requests examination or treatment for an emergency medical condition. ${ }^{35}$ A hospital would also incur an EMTALA screening obligation if the individual was unable to make a verbal request but displayed symptoms that indicated a clear possibility of an emergency medical condition. ${ }^{36}$ Under such a screening obligation, it is not required that an emergency medical condition actually be found to exist upon subsequent examination. Rather, in the absence of an actual screening request, a request is deemed to exist if a prudent layperson observer would believe, based on the individual's

28 § 1395dd(a); Chiles, supra note 3, at 559.

$29 \$ 1395 \mathrm{dd}(\mathrm{b})(1) ;$ see Chiles, supra note 3, at 566-67.

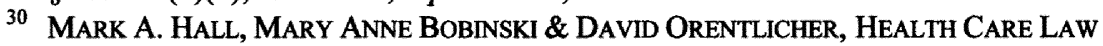
AND ETHICS 124 (Aspen 6th ed. 2003 \& Supp. 2006) (supplement available at http://indylaw. indiana.edu/instructors/orentlicher/healthlw/Chap2A1.html).

${ }^{31}$ Id.

32 Id. (citing Cherukuri v. Shalala, 175 F.3d 446 (6th Cir. 1999) (dismissing EMTALA claims against a physician at a small rural hospital who transferred two patients who needed a particular surgery to stop internal bleeding from an automobile accident)).

${ }^{33}$ Amy J. McKitrick, Note, The Effect of State Medical Malpractice Caps on Damages Awarded Under the Emergency Medical Treatment and Active Labor Act, 42 CLEV. ST. L. REV. 171, 176 (1994).

$34 \quad 42$ C.F.R. $\S 489.24(b)(1)(2006)$.

${ }^{35}$ Id. $\S 489.24(\mathrm{~b})(2)$.

36 Id. $\$ 489.24(\mathrm{~b})$. 
symptoms, that the individual needed emergency care. ${ }^{37}$ A hospital's obligations cease once the patient has been admitted to the hospital as an inpatient. ${ }^{38}$

Hospitals that fail to provide an appropriate medical screening or to stabilize an emergency condition are subject to heavy civil penalties under EMTALA. $^{39}$ EMTALA creates a private cause of action for damages against such hospitals when an individual suffers harm as a direct result of a hospital's EMTALA violation. This provision, at issue in this Note, states:

Any individual who suffers personal harm as a direct result of a participating hospital's violation of a requirement of this section may, in a civil action against the participating hospital, obtain those damages available for personal injury under the law of the State in which the hospital is located, and such equitable relief as is appropriate. $^{40}$

A large portion of the courts' EMTALA decisions have focused on the interpretation and application of this provision.

The disagreement among courts concerning the applicability of state damage caps to EMTALA claims is primarily a result of the ambiguity of the aforementioned damages provision, and in particular, the language permitting an individual to "obtain those damages available for personal injury under the law of the State ...." When an EMTALA claim seems to implicate medical malpractice issues, the confusion surrounding the applicability of state medical malpractice damage caps under the EMTALA damages provision becomes a primary concern for physicians, potential plaintiffs, attorneys, and courts. Specifically, courts must determine whether "personal injury" damages include those available for medical malpractice claims. Courts faced with this should consider multiple factors including, but not limited to, the following: the congressional purpose, legislative history, and relevant policies underlying both EMTALA and medical malpractice statutes and the potential implications the court's decision will have for professional liability and the general cost of and access to health care.

\section{B. The Medical Liability Crisis and Tort Reform: A General Framework of State Medical Malpractice Statutes and the Effects of Damage Caps}

At the local level, states have statutorily imposed medical malpractice damage caps as an element of general tort and medical liability reform in re-

37 Id.

38 Id. $\$ \S 489.24(\mathrm{a})(\mathrm{ii}),(\mathrm{d})(2)$.

3942 U.S.C. $\S 1395 \mathrm{dd}(\mathrm{d})(1)-(2)$ (2000); Chiles, supra note 3, at 559, 567.

$40 § 1395 \mathrm{dd}(\mathrm{d})(2)(\mathrm{A})$. 
sponse to the medical malpractice crisis occurring across many states as a result of "the nation's out-of-control legal system ...., The current system is forcing physicians to retire early, relocate, or refrain from performing high-risk medical procedures. ${ }^{42}$ Everyday, there are more than 120,000 malpractice actions pending against physicians in the United States, and one-sixth of American physicians report a claim against them each year. ${ }^{43}$ These numbers are even higher for high-risk specialties. ${ }^{44}$ The amount of malpractice verdicts in states with uncapped medical liability is even more astounding. ${ }^{45}$ For example, Texas reported a $\$ 606$ million verdict in $2005,{ }^{46}$ Pennsylvania had multiple verdicts of more than fifty million dollars each, and together, New York and Pennsylvania paid nearly one billion dollars in malpractice indemnity in $2000 .^{47}$ In order to pay such unlimited judgments, insurers must charge unlimited premiums. $^{48}$

Some states have declared themselves to be amidst a medical liability crisis as a result of the staggering increase in the cost of malpractice insurance and the consequent decrease in access to critical medical services. ${ }^{49}$ Soaring medical malpractice insurance rates and the increased exposure to liability in the United States has resulted, at least in part, from the escalating costs of defending malpractice claims, which are inevitably linked to the increase in both the volume of such litigation and the size of plaintiffs' awards. ${ }^{50}$ Thus, in an effort to combat the rising costs of malpractice insurance premiums resulting from excessive awards to plaintiffs in malpractice litigation, state legislatures have included various forms of damage cap provisions in their state medical malpractice statutes. $^{51}$

41 MediCAL LIABILITY CRISIS MAP, supra note 13.

42 Id.

43 Anderson, Defending the Practice, supra note 11.

44 Some high-risk specialties include neurosurgery, orthopedics, obstetrics, trauma surgery, emergency medicine, and plastic surgery. Id. As one example of the heightened crisis within high-risk specialties, one in seven obstetricians no longer delivers babies because of the rising cost of liability insurance and the fear of being sued. AM. MED. Ass'N, AMERICA's MEDICAL LIABILITY CRISIS, MEDICAL LIABILITY REFORM FAST FACTS (2006), http://www.amaassn.org/ama1/pub/upload/mm/399/mlr_fastfacts.pdf.

45 Anderson, Defending the Practice, supra note 11.

46 A jury found a cancer clinic was responsible for the death of an eighty-two-year-old man who died after receiving an overdose of chemotherapy drugs. Featherston $\mathrm{v}$. Richardson Hosp., No. 03-08488 (Dallas County Dist. Ct., Tex. Mar. 4, 2005). This medical malpractice suit was filed prior to the 2003 enactment of Texas' $\$ 250,000$ cap on non-economic damages. See Natalie White, Overdose of Chemotherapy Meds Leads to \$606 Million Verdict, LAWYERS USA, 2006 Special Feature, available at http://www.lawyersweeklyusa.com/usa/2topten 2005.cfm.

47 Anderson, Defending the Practice, supra note 11.

48 Id. at 1177.

49 Id. at 1173 (including specialties, such as obstetrics and trauma care).

50 Anderson, Effective Legal Reform, supra note 11, at 344.

51 California passed the Medical Injury Compensation Reform Act of 1975 ("MICRA") 
Medical malpractice damage caps limit the damages recoverable by an injured plaintiff and those whose claims against a health care provider derive from the patient's injury. ${ }^{52}$ While all fifty states have some form of medical malpractice liability statute, the type of damage cap provided varies from state to state. ${ }^{53}$ States with damage caps may have either a mandatory ${ }^{54}$ or a discretionary cap restriction. ${ }^{55}$ Some specific forms of damage restrictions include limits on non-economic damages, ${ }^{56}$ limits on either general or punitive damages, ${ }^{57}$ and limits on all damages except for medical care and related expenses. $^{58}$

and since has seen a premium rate decrease of forty percent. Anderson, Defending the Practice, supra note 11. The four major components of MICRA include: 1) a $\$ 250,000$ cap on noneconomic damages; 2) defendants may introduce into evidence additional sources of compensation for injury that have already been paid (collateral source reform); 3) periodic payments of damage awards; and 4) limits on contingency fees using a sliding scale. Anderson, Effective Legal Reform, supra note 11, at 350. Indiana also passed comprehensive reforms around the same time as California and now enjoys some of the lowest malpractice insurance rates in the country. Anderson, Defending the Practice, supra note 11. In contrast, Oregon has seen dramatic rate increases since its supreme court invalidated a twelve-year-old $\$ 500,000$ cap on noneconomic damages in 1999. Id.; see Lakin v. Senco Prod., 987 P.2d 463, 474 (Or. 1999).

Plaintiff's attorneys and other groups that believe current levels of malpractice litigation are not excessive assert that today's high premiums are not caused by increasing claims costs but are instead a result of insurance company mismanagement and poor investments. Anderson, Defending the Practice, supra note 11, at 1175.

52 Carol A. Crocca, Annotation, Validity, Construction, and Application of State Statutory Provisions Limiting Amount of Recovery in Medical Malpractice Claims, 26 A.L.R. 5th 245 (1995).

${ }^{53}$ Mark D. Clore, Medical Malpractice Death Actions: Understanding Caps, Stowers, and Credits, 41 S. TEX. L. REV. 467, 471, 509 (2000) (summarizing state damage cap provisions as of 1998).

${ }^{54}$ See, e.g., CAL. CIV. CODE $\S 3333.2$ (West 1997 \& Supp. 2007) (limiting noneconomic damages to $\$ 250,000$ ); IND. CODE $\S 34-18-14-3$ (2004) (limiting damages to a total of $\$ 1.25$ million and $\$ 250,000$ on damages recoverable from each health care provider; excess paid through Patient Compensation Fund).

55 See Clore, supra note 53, at 471.

56 See, e.g., CAL. CIV. CodE $\S 3333.2$ (West 1997 \& Supp. 2007); Mo. ANN. STAT. § 538.210 (West $2000 \&$ Supp. 2006) (placing a $\$ 350,000$ cap on non-economic damages per plaintiff); WIS. STAT. ANN. $\$ 893.55$ (West 2006) (placing a $\$ 750,000$ cap per occurrence on or after Apr. 6, 2006, on non-economic damages).

${ }_{57}$ See, e.g., FLA. STAT. ANN. $\$ \S 766.118(2)(a),(4)(a), 768.73(1)(a)$ (West 2005) (limiting recovery to $\$ 500,000$ per claimant on non-economic damages and $\$ 150,000$ per claimant for practitioners providing emergency services; limiting punitive damages to three times the amount of compensatory damages awarded or $\$ 500,000$, whichever is greater).

${ }_{58}$ Clore, supra note 53, at 471; see, e.g., VA. CODE ANN. $\$ \S 8.01-38.1,8.01-581.15$ (2000 \& Supp. 2006) (limiting all damages except for medical care and related expenses, including a $\$ 350,000$ cap on punitive damages and a total limit of $\$ 1.5$ million in 1999 with increases of $\$ 50,000$ each year until 2007 and then an increase of $\$ 75,000$ in 2007 and 2008).

According to the AMA's Advocacy Resource Center, the following nineteen states do not have a cap on non-economic damages (as of February 2007): Alabama, Arizona, Arkansas, Connecticut, Delaware, Iowa, Kentucky, Minnesota, New Hampshire, New Jersey, New York, North Carolina, Oregon, Pennsylvania, Rhode Island, Tennessee, Vermont, Washington, and 
Clearly, such damage caps would apply to claims of malpractice, or medical negligence, but since the enactment of EMTALA, plaintiffs have often filed what are essentially medical malpractice-based suits under the guise of an EMTALA claim, possibly in order to circumvent the application of state damage caps, thus affording them an opportunity to obtain a larger award. As a result, courts have faced the challenge of interpreting EMTALA's language to determine whether damages for personal injury include those available for medical malpractice claims, and thus whether state damage caps apply to EMTALA claims. Ultimately, courts must consider, when determining the applicability of state damage caps to EMTALA claims, whether they want to open the door for potential plaintiffs to circumvent state damage caps by framing a malpractice-based claim as a federal EMTALA claim.

\section{ARGUMENTS For AND AGAINST APPLYING STATE MEDICAL MALPRACTICE DAMAGE CAPS TO EMTALA}

\section{A. The Minority View: Unlimited Damages Through Failing to Apply State Damage Caps to EMTALA Claims}

While the majority of courts have interpreted EMTALA to incorporate state damage caps, a few courts have declined to apply medical malpractice damage caps to EMTALA claims. ${ }^{59}$ Typically, when determining whether a particular state damage cap applies to an EMTALA claim, federal courts look at the underlying conduct being challenged and the legal theory on which it is being challenged in order to ascertain whether, if brought under state law, it would constitute a cause of action subject to the cap. ${ }^{60}$ While the district court's decision in Power was ultimately reversed by the Fourth Circuit, ${ }^{61}$ its reasoning highlights the primary arguments against applying a state damage cap to an EMTALA claim. It is helpful to distinguish the analyses of the district court and the Fourth Circuit, in addition to other courts, in order to better understand the varying statutory constructions of EMTALA that have been used by courts to determine whether to incorporate state medical malpractice damage caps.

Wyoming. Advocacy Res. CrR., AM. Med. Ass'N, CAPS on Damages (2007). While Louisiana's damage cap was ruled unconstitutional by the Louisiana Court of Appeal in Arrington $v$. ER Physicians Group, 04-1235 (La. App. 3 Cir. 9/27/06); 940 So. 2d 777, 784, this decision was recently vacated and set aside by the Supreme Court of Louisiana in Arrington v. GalenMed, Inc., 06-2968 (La. 2/2/07) (holding that constitutional challenges to statutes must be raised and specially pleaded in the trial court).

59 E.g., Power v. Arlington Hosp. Ass'n, 800 F. Supp. 1384, 1392 (E.D. Va. 1992) [hereinafter Power I], rev'd, 42 F.3d 851 (4th Cir. 1994).

${ }^{60}$ Barris v. County of Los Angeles, 972 P.2d 966, 974 (Cal. 1999); see Smith v. Botsford Gen. Hosp., 419 F.3d 513, 518 (6th Cir. 2005), cert. denied, 126 S. Ct. 1912 (2006) (mem.); Power v. Arlington Hosp. Ass'n, 42 F.3d 851, 862 (4th Cir. 1994) [hereinafter Power II].

${ }^{61}$ See discussion infra Part III.B.2. 


\section{Virginia: Power v. Arlington Hospital Ass'n I}

In Power I, the plaintiff filed suit in federal district court alleging that the transferring hospital failed to appropriately screen her for an emergency condition, stabilize her medical condition, and provide her medical records to the receiving hospital in the transfer as required under EMTALA. ${ }^{62}$ She was awarded five million dollars in damages, despite the one million dollar statutory cap Virginia placed on medical malpractice claims. ${ }^{63}$

In its analysis, the district court interpreted the language "damages available" in $\S 1395 \mathrm{dd}(\mathrm{d})(2)(\mathrm{A})$ of EMTALA to "plainly mean [ ] ... those elements of damage for which recovery is permitted under state law." ${ }^{.64}$ The court also stated that the "language of $1395 \mathrm{dd}(\mathrm{d})([2])(\mathrm{A})$ is refreshingly clear and simple: the damages available for 'patient dumping' actions are the state's personal injury damages." ${ }^{65}$ The court determined that there were no limits on personal injury claims in Virginia, and recovery under EMTALA was not limited to "damages available for personal injury except as may be limited in certain states by medical malpractice statutes." ${ }^{, 66}$ The court interpreted EMTALA very narrowly to find that damages for personal injury included only personal injury

62 Power I, supra note 59, at 1386-87. The plaintiff presented to the emergency room at a Virginia hospital, complaining of chills and pain in her hip. Id. at 1386. She was examined by two physicians who took her vital signs, conducted a hip x-ray, and performed a urinalysis. Id. Although the physicians' diagnosis was uncertain, they diagnosed her with a possible neurological or musculoskeletal condition. Id. The plaintiff was discharged two hours later with a prescription for pain medication and was told to return if her condition worsened. Id. The next day, the plaintiff was again admitted to the hospital. Id. She stayed in the hospital for four months during which both of her legs were amputated and she became blind in one eye. Id. She was finally transferred by defendant hospital to a hospital in Great Britain. Id.

63 Power II, supra note 60, at 854. At the time of Power I, Virginia's medical malpractice cap provided that "[i]n any verdict returned against a health care provider in an action for malpractice ... which is tried by a jury ... the total amount recoverable for any injury to, or death of, a patient shall not exceed one million dollars." VA. CODE ANN. § 8.01-581.15 (1992), cited in Power I, supra note 59, at 1387.

"Malpractice" was defined in the statute as "any tort based on health care or professional services rendered, or which should have been rendered, by a health care provider, to a patient." VA. CODE ANN. § 8.01-581.1 (1992), cited in Power II, supra note 60, at 861. Under the statute, "health care" was defined as "any act, or treatment performed or furnished, or which should have been performed or furnished, by any health care provider for, to, or on behalf of a patient during the patient's medical diagnosis, care, treatment or confinement." Id., cited in Power II, supra note 60, at 861.

${ }_{64}^{64}$ Power I, supra note 59, at 1388, cited in Power II, supra note 60.

65 Id.

${ }^{66} I d$. at 1389. 
and not malpractice damages. ${ }^{67}$ By inference, however, personal injury could include negligence, including malpractice, damages. ${ }^{68}$

Nonetheless, the district court went on to distinguish the term "personal injury," as used in $\S 1395 \mathrm{dd}(\mathrm{d})(2)(\mathrm{A})$, from the term "malpractice," and then pointed out that there is a "conspicuous absence from the EMTALA "patient dumping' provision of any limiting language." these points to bolster its conclusion that $\S 1395 \mathrm{dd}(\mathrm{d})(2)(\mathrm{A})$ limited Ms. Power's damages to only the elements allowed under Virginia law for personal injury, ${ }^{70}$ and that if Congress had intended to incorporate malpractice damage caps into EMTALA, it "would surely have chosen more precise language."71

The court further reasoned that EMTALA was neither a tort nor a negligence action; rather, it was a "sui generis federal statutory action."72 In addition, applying a state damage cap would conflict with Congress's objectives behind EMTALA, which were to deter patient dumping and to compensate those who were illegally dumped. ${ }^{73}$ Furthermore, these goals would be hindered by low state recovery caps. ${ }^{74}$

67 See id.; Heather K. Bardot, COBRA Strikes at Virginia's Cap on Malpractice Actions: An Analysis of Power v. Arlington Hospital [,Ass'n], 2 GeO. MASON IND. L. REV. 249, 256 (1993).

68 Black's Law Dictionary defines "personal injury" as "[i]n a negligence action, any harm caused to a person." BLACK's LAW DICTIONARY 802 (8th ed. 2004); see Bardot, supra note 67 , at 257 .

${ }^{69}$ Power I, supra note 59, at 1389.

70 According to Virginia's Model Jury Instructions, the elements that are considered when determining damages for personal injury are: 1) any bodily injuries he sustained and their effect on his health according to their degree and probable duration; 2) any physical pain (and mental anguish] he suffered in the past [and any that he may be reasonably expected to suffer in the future]; 3) any disfigurement or deformity and any associated humiliation of embarrassment; 4) any inconvenience caused in the past [and any that probably will be caused in the future]; 5) any medical expenses incurred in the past [and any that may be reasonably expected to occur in the future]; 6) any earnings he lost because he was unable to work ...;7) any loss of earnings and decrease in earning capacity, or either, that he may reasonably be expected to sustain in the future; 8 ) any property damage he sustained. Id. at 1388 (brackets in original) (citing Virginia's Model Jury Instructions, Inst. No. 9.000 (1988)).
71 Id. at 1390.
72 Id. at 1391.
${ }^{73}$ Id. at 1392.
${ }^{74} \mathrm{Id}$. 


\section{Florida: Cooper v. Gulf Breeze Hospital, Inc.}

In Cooper v. GulfBreeze Hospital, Inc., ${ }^{75}$ the court also held that the state damage cap ${ }^{76}$ did not apply to the plaintiff's EMTALA claim. ${ }^{77}$ It reasoned that EMTALA creates a cause of action based on strict liability, distinct from malpractice causes of action, which are based on negligence. ${ }^{78}$ The court also discussed the Indiana decision of Reid v. Indianapolis Osteopathic Medical Hospital ${ }^{79}$ which held that EMTALA does not incorporate state procedural requirements in medical malpractice statutes but does incorporate state substantive damage caps. ${ }^{80}$ The Cooper court noted, however, that Florida's statute was schematically different from Indiana's statute in Reid and Virginia's statute in Power $\mathrm{I}^{81}$ because Florida's law "conditions damage caps on the pre-suit procedures followed by the parties." ${ }^{\circ 2}$ Thus, it was unclear to the court whether Reid would support incorporating damage caps when this would require incorporating procedural requirements as well. ${ }^{83}$ Ultimately, the court found that the plaintiff's EMTALA claim was not limited by Florida's medical malpractice statute. $^{84}$

\section{California: Jackson v. East Bay Hospital}

Considering the purpose and intent of EMTALA and the relevant legislative history, the court in Jackson v. East Bay Hospital ${ }^{85}$ also refused to apply

${ }^{75}$ Cooper v. Gulf Breeze Hosp. Inc., 839 F. Supp. 1538, 1540 (N.D. Fla. 1993) (involving a patient who went to the emergency room after suffering a stroke, was discharged with instructions to see his heart doctor, and later suffered from paralysis and speech problems; patient filed an EMTALA suit against the hospital for discharging him without first stabilizing his condition).

${ }^{76}$ Florida's medical malpractice statute provided that either a potential plaintiff or defendant may offer to arbitrate the amount of damages in a malpractice action rather than have the issue go to trial. Id. at 1542 (citing FLA. STAT. ANN. $§ 766.206$ (West 1993)). If the potential plaintiff refuses to arbitrate, then his or her recovery for non-economic damages is capped at $\$ 350,000$ per incident of malpractice. Id.

77 Id. at 1543 (stating that EMTALA does not incorporate Florida's medical malpractice law and thus does not incorporate damage limits on malpractice actions).

${ }^{78}$ Id. at 1542; see also Williams v. Birkeness, 34 F.3d 695, 697 (8th Cir. 1994). While most often, medical malpractice claims are based on theories of negligence, plaintiffs have based medical malpractice claims on strict liability theories as well. See Hoven v. Kelble, 256 N.W.2d 379 (Wis. 1977) (medical malpractice claim based on a theory of strict liability, although court ultimately refused to apply that theory).

79 Reid v. Indianapolis Osteopathic Med. Hosp., 709 F. Supp. 853 (S.D. Ind. 1989).

${ }^{80}$ Id. at 855-56, cited in Cooper, 839 F. Supp. at 1543.

81 Power I, supra note 59.

82 Cooper, 839 F. Supp. at 1543.

83 Id.

${ }^{84} I d$.

85 Jackson v. E. Bay Hosp., 980 F. Supp. 1341, 1344, 1346 (N.D. Cal. 1997) (plaintiff 
the state damage cap on medical malpractice suits to EMTALA claims because, according to the court, EMTALA incorporated state caps on personal injury claims but not those caps that are specific to medical malpractice claims. ${ }^{86}$ In its reasoning, the court stated that "EMTALA clearly incorporates state law in the determination of damages," but the extent or scope of that incorporation is the ultimate issue. ${ }^{87}$ The court concluded that because its medical malpractice statute, MICRA, ${ }^{88}$ does not extend to all tort claims but rather only to those actions "based on professional negligence," the damage cap did not apply to an EMTALA cause of action. ${ }^{89}$ Without a showing of negligence, the court refused to apply the damage cap to the EMTALA claim. ${ }^{90}$ Although this case law offers seemingly persuasive reasons to exclude damage caps from EMTALA claims, the majority of courts have held otherwise based on more compelling reasons that focus on the plain language of EMTALA, legislative purpose, and policy.

\section{B. The Majority View: Limiting Damages By Applying State Damage Caps to EMTALA Claims}

\section{The Sixth Circuit: Smith v. Botsford General Hospital}

Recently, in an issue of first impression, the United States Court of Appeals for the Sixth Circuit joined the majority of courts ${ }^{91}$ and held that Michigan's cap on malpractice damages applies to federal EMTALA claims, thus limiting the amount of damages a plaintiff can recover for his or her EMTALA claim. ${ }^{92}$ In Smith v. Botsford General Hospital, the plaintiff alleged that the defendant hospital violated EMTALA when it failed to stabilize the deceased's condition before transporting him. ${ }^{93}$ On appeal, the hospital contended that the non-economic damages awarded by the jury ( $\$ 5$ million) following trial in the

asserted that several doctors and nurses witnessed patient go into cardiac arrest and still transferred him to another hospital instead of providing treatment in violation of EMTALA), aff' $d$ on other grounds, 246 F.3d 1248, 1262 (9th Cir. 2001).

${ }^{86}$ Id. at $1348-50$.

87 Id. at 1346.

88 Medical Injury Compensation Reform Act of 1975 (MICRA), CAL. Crv. CoDE $\S 3333$ (West 1997 \& Supp. 2007).

89 Jackson, 980 F. Supp. at 1350

90 Id.

91 See, e.g., Barris v. County of Los Angeles, 972 P.2d 966, 973 (Cal. 1999); Reid v. Indianapolis Osteopathic Med. Hosp., Inc., 709 F. Supp. 853, 855-56 (S.D. Ind. 1989), cited in Power II, supra note 60, at 862-63; Feighery v. York Hosp., 38 F. Supp. 2d 142, 158 (D. Me. 1999); Lee v. Alleghany Reg'1 Hosp. Corp., 778 F. Supp. 900, 903-04 (W.D. Va. 1991) (following reasoning in Reid). Most federal courts that have addressed the issue have also applied particular state caps on malpractice damages to EMTALA claims. Cal. High Court Upholds MICRA Damage Limits, 3-7 MEALEY's MANAGED CARE LIABILITY REP. 10 (1999).

92 Smith v. Botsford Gen. Hosp., 419 F.3d 513, 519 (6th Cir. 2005), cert. denied, 126 S. Ct. 1912 (2006) (mem.).

93 Id. at 515. 
district court should be reduced according to the state's malpractice cap, which limits non-economic damages " in an action for damages alleging medical malpractice' to $\$ 359,000$.",94

In reaching its decision, the court examined the plain language of EMTALA's damages provision, which reads that "[a]ny individual who suffers personal harm as a direct result of a participating hospital's violation of a requirement of [the Act] may, in a civil action against the participating hospital, obtain those damages available for personal injury under the law of the State in which the hospital is located." 95 Based on this language, the court reasoned that "damages available" could be interpreted broadly to mean the amount of damages for which recovery is permitted under state law because nothing in the language indicates otherwise. ${ }^{96}$ The plaintiff argued, however, that the statute required courts to consider only the types of damages recoverable under state law, and not the amount. ${ }^{97}$ The court rejected this assertion stating, "[W]e see nothing in the language of the section indicating that 'damages available' does not also mean the amount of damages for which recovery is permitted under state law." 98

The court went on to analyze the application of the state damage cap to the EMTALA claim, using the framework set forth in the Fourth Circuit decision, Power v. Arlington Hospital Ass ' $n,{ }^{99}$ which provided that the starting point for determining whether a state damage cap applies and what damages are available is the threshold question of whether the plaintiff's EMTALA claim would be deemed a malpractice claim under state law. ${ }^{100}$ Thus, if an EMTALA claim can be deemed a medical malpractice claim under state law, it is governed by that state's medical malpractice statutes, and the damage cap provision will likely apply. ${ }^{101}$ If a court finds that the claim would not constitute a medical malpractice claim specifically, the state medical malpractice statute would not govern the EMTALA claim, and the damage cap would not apply. ${ }^{102}$

The test applied by the court to determine "whether the nature of a claim is ordinary negligence or medical malpractice" consisted of two parts: 1) " "whether [the claim] is being brought against someone who, or an entity that, is capable of malpractice""103 and 2) whether the claim "sounds in medical

${ }^{94} I d$. at 517 (stating that Michigan's statute actually caps damages at $\$ 280,000$, but this amount changes as a result of yearly adjustments; 2003 adjustment applicable in Smith capped damages at $\$ 359,000$ ); Mich. Comp. LAws ANN. $\$ 600.1483$ (West 1996 \& Supp. 2006).

95 Smith, 419 F.3d at 517 (first emphasis added) (quoting 42 U.S.C. $§ 1395 \mathrm{dd}(\mathrm{d})(2)(\mathrm{A})$ (2000)).

96 Id.

97 Id.

98 Id. (citing Power II, supra note 60).

99 Power II, supra note 60; see discussion infra Part III.B.2.

100 Smith, 419 F.3d at 518.

101 See id.; see also Power II, supra note 60.

102 See Smith, 419 F.3d at 518.

103 Id. (quoting Bryant v. Oakpointe Villa Nursing Ctr., Inc., 684 
malpractice."104 The second part of the test turns on the additional questions of "1) whether the claim pertains to an action that occurred within the course of a professional relationship; and 2) whether the claim raises questions of medical judgment beyond the realm of common knowledge and experience." ${ }^{\prime 105}$ If these questions are answered in the affirmative then the action is subject to the procedural and substantive requirements that govern medical malpractice claims. ${ }^{106}$ When analyzing the issue of medical judgment, the court stated that the distinguishing feature of claims involving medical judgment is the need for expert testimony. ${ }^{107}$ Applying this standard, the court determined that the EMTALA failure-to-stabilize claim at issue in the case constituted a malpractice claim because compliance with the stabilization requirements of EMTALA entails medical judgment understood only through expert testimony. ${ }^{108}$ Therefore, the damages in the case were limited by the state cap. ${ }^{109}$

\section{The Fourth Circuit: Power v. Arlington Hospital Ass' $n$ II}

Reversing the district court's decision ${ }^{110}$ in Power I, the Fourth Circuit also held that the plaintiff's EMTALA claim was a "malpractice claim" subject to Virginia's medical malpractice damage cap. ${ }^{111}$ In its analysis, the court noted that "EMTALA is not a substitute for state law malpractice actions, and was not intended to guarantee proper diagnosis or to provide a federal remedy for misdiagnosis or medical negligence."112

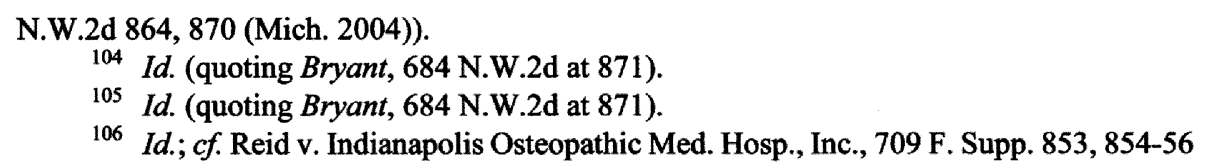

(S.D. Ind. 1989) (holding that the state procedural limitation requiring a medical review panel to examine a claim before going to trial does not apply to EMTALA claims but the substantive damage cap limitation does apply).

${ }_{107}$ Smith, 419 F.3d at 518 (citing Bryant, 684 N.W.2d at 872) ("If the reasonableness of the health care professionals' action can be evaluated by lay jurors, on the basis of their common knowledge and experience, it is ordinary negligence. If, on the other hand, the reasonableness of the action can only be evaluated by a jury only after having been presented the standards of care pertaining to the medical issue before the jury explained by experts, a medical malpractice claim is involved.").

108 Id. Under EMTALA, the health care provider must stabilize to the extent that it is assured, "within reasonable medical probability, that no material deterioration of the condition is likely ...." 42 U.S.C. $\S 1395 \mathrm{dd}(\mathrm{e})(3)(\mathrm{A})$ (2000) (emphasis added).

109 Smith, 419 F.3d at 519.

110 See supra Part III.A.1.

111 Power II, supra note 60, at 860. The plaintiff in this case "cleverly" framed her action under EMTALA instead of suing in state court under the medical malpractice statute. Bardot, supra note 67, at 249, 255.

112 Power II, supra note 60, at 856 (citing Brooks v. Maryland Gen. Hosp., Inc., 996 F.2d 708, 710 (4th Cir. 1993); Baber v. Hosp. Corp. of Am., 977 F.2d 872, 880 (4th Cir. 1992)). 
By including the EMTALA damages provision, ${ }^{113}$ the court stated that Congress explicitly directed federal courts to look to state law in the state where the hospital is located to determine both the type and amount of damages available in EMTALA actions. ${ }^{114}$ Therefore, to determine whether the state malpractice cap applied, the court focused on the threshold issue of whether the plaintiff's EMTALA claim would be deemed a malpractice claim under Virginia's medical malpractice statute. ${ }^{115}$ Clarifying this issue, the court stated that its initial inquiry was whether Virginia's malpractice cap would apply to a personal injury claim against a hospital that alleges a disparate provision of health care services, but does not allege a breach of the prevailing standard of care. ${ }^{116}$

The court in Power II first relied on three Virginia Supreme Court cases in its statutory construction and general reasoning. ${ }^{117}$ This precedent demonstrated, according to the circuit court, the Virginia Supreme Court's desire to broadly construe the statutory language enacted by the Virginia General Assembly in defining a cause of action for malpractice. ${ }^{118}$

First, in Glisson v. Loxley, the Virginia Supreme Court held that the patient's battery claim was subject to the requirements of Virginia's medical malpractice statute because battery is a tort. ${ }^{119}$ The statute defined malpractice as "any tort based on health care."120 Therefore, although the battery claim was covered by the malpractice statute, the patient's breach of contract claim was not. $^{121}$

Second, in Gonzalez v. Fairfax Hospital System, Inc., the court held that a suit against a hospital for negligence ${ }^{122}$ constituted a malpractice claim under Virginia's statute because the alleged negligent acts occurred while the patient was receiving treatment or "health care" as a patient at the hospital. ${ }^{123}$ In addition, "the alleged tort was based on "health care or professional services rendered ... to a patient,' which constitutes 'malpractice'," and the hospital was a health care provider. ${ }^{124}$ Thus, applying a broad, plain meaning approach to the

113 For the exact language of the provision, see supra text accompanying note 40.

114 Power II, supra note 60, at 860.

115 Id. (citing Brooks, 996 F.2d at 713).

$116 I d$. at 860-61 (citing Brooks, 996 F.2d at 713).

117 See id. at 861 (citing Gonzalez v. Fairfax Hosp. Sys. Inc., 389 S.E.2d 458 (Va. 1990); Hagan v. Antonio, 397 S.E.2d 810 (Va. 1990), superseded by statute, VA. CODE ANN. $§ 8.01$ 581.2 (1993); Glisson v. Loxley, 366 S.E.2d 68 (Va. 1988), superseded by statute, VA. CoDE ANN. § 8.01-581.2 (1993)).

118 Id. (Glisson and Hagan interpreted a prior version of Virginia's medical malpractice statute, as stated in McDonald v. Hoard, 48 Va. Cir. 421, 427 (1999)).

119 Glisson, 366 S.E.2d at 72, cited in Power II, supra note 60, at 861.

120 Id., quoted in Power II, supra note 60, at 861.

121 Id., cited in Power II, supra note 60, at 861.

122 The plaintiff alleged that he was injured in a whirlpool tub by a metal object during physical therapy. Gonzalez, 389 S.E.2d at 458.

123 Id. at 459.

124 Id. (quoting VA. CODE ANN. $§ 8.01-581.1(1990)$ ). 
statute, the court found that the malpractice statute's requirement that a defendant receive notice of a claim applied to the plaintiff's EMTALA claim. ${ }^{125}$

Finally, in Hagan v. Antonio, the court held that an allegation of improper sexual conduct by a physician during his physical examination of a patient was an action for "malpractice" requiring the statutory notice provided in Virginia's medical malpractice statute. ${ }^{126}$ According to the court, the defendant physician's conduct constituted malpractice because "legitimate or improper, [it] was 'based on' an 'act' by a health care provider to 'a patient during the patient's medical . . . care.""127 Thus, the defendant's alleged tortious conduct was "based on health care or professional services rendered," within the meaning of the state's malpractice statute because it "stemmed from, arose from, and was 'based on' the performance of a physical examination."128 This interpretation of the type of conduct required to constitute malpractice under the statute also suggests and further supports a broad reading of this particular malpractice statute.

Applying the same broad interpretation to the plaintiff's EMTALA claim, the court in Power II concluded that it would be deemed a malpractice claim under the state's medical malpractice statute. ${ }^{129}$ The court reasoned that the conduct that formed the basis of the plaintiff's EMTALA claim occurred while the plaintiff was receiving "health care" from a health care provider, as defined by the statute. ${ }^{130}$ Furthermore, the court found that the tort alleged in the plaintiff's EMTALA claim was "based on health care or professional services rendered, or which should have been rendered ... to a patient,"131 thus falling within the state's statutory definition of malpractice. ${ }^{132}$

The Fourth Circuit further emphasized that EMTALA was not intended only to incorporate damage caps for personal injury claims. Rather, courts should determine whether the underlying conduct and the legal basis for the claim would be encompassed within the state's personal injury damage cap, the medical malpractice damage cap, both, or neither, if brought under state law. ${ }^{133}$ The problem with this interpretation, as the Fourth Circuit noted, is that the damages available under EMTALA will vary from state to state according to the type and amount of the state's damage caps. ${ }^{134}$ The court reasoned, however, that this result is unavoidable because it is inherent in $\S$

125 Id. at 459-60.

126 Hagan v. Antonio, 397 S.E.2d 810, 812 (Va. 1990), superseded by statute, VA. CODE ANN. § 8.01-581.2 (1993).

127 Id., quoted in Power II, supra note 60, at 861.

128 Id. at 811-12.

129 Power II, supra note 60, at 861.

$130 \mathrm{Id}$.

131 Id.

132 Id.

133 Id. at 863.

134 Id. 
1395dd(d)(2)(A)'s explicit direction that courts look to state law to determine what damages are available. ${ }^{135}$ Furthermore, while the Fourth Circuit agreed that the language in $\S 1395 \mathrm{dd}(\mathrm{d})(2)(\mathrm{A})$ applies to elements of damages, nothing in the language of the section indicated that "damages available" did not also mean the amount of damages for which recovery is permitted under state law. ${ }^{136}$ Moreover, the Fourth Circuit disagreed with the district court in its assertion that Congress was required to explicitly refer to or limit malpractice damage caps in order for $\S 1395 \mathrm{dd}(\mathrm{d})(2)(\mathrm{A})$ to incorporate state malpractice damage caps. ${ }^{137}$ Rather, $\S 1395 \mathrm{dd}(\mathrm{d})(2)(\mathrm{A})$ reflected Congress's deliberate choice to use the more general and inclusive phrase "personal injury" so that it would not have to explicitly refer to "each and every type of limitation on damages, e.g. limitations on punitive damages, noneconomic losses, and malpractice damage caps, that the states might have enacted."138 Thus, Congress was not required to refer specifically to malpractice damage caps or to use other explicit limiting language in order to incorporate such limits. ${ }^{139}$

The Fourth Circuit also pointed to the legislative history to support this interpretation. ${ }^{140}$ When the bill was initially proposed, there were no limitations on the damages provision. ${ }^{141}$ There were concerns, however, regarding "the potential impact of these enforcement provisions on the current medical malpractice crisis" and that smaller hospitals would have to close their emergency rooms if the EMTALA penalties were too severe. ${ }^{142}$ Thus, in subsequent modifications of the bill, on the issue of damages, the courts were directed to "apply the law of the State in which the violating hospital is located, for actions brought by a harmed individual ...."143 Thus, the Fourth Circuit concluded that Congress "was clearly aware of a growing concern in some states that excessive damage awards were fueling a medical malpractice "crisis"..." therefore had wanted to preserve state-enacted ceilings on the amount of dam-

135

136 Id. at 862.

137 Id.

138 Id. (citing an amicus brief prepared by the Virginia Hospital Association); accord Barris v. County of Los Angeles, 972 P.2d 966, 973 (Cal. 1999) (holding that EMTALA expressly incorporates state substantive limits on "damages available for personal injury," 42 U.S.C. $\S 1395 \mathrm{dd}(\mathrm{d})(2)(\mathrm{A})(2000)$, because Congress's choice of "personal injury" was intended to be inclusive, such that EMTALA incorporates not only general provisions for personal injury damages but also specific provisions such as limits applicable to malpractice damages).

139 Power II, supra note 60.

140 Id.

141 Id.

142 Id. (citing H.R. REP. No. 99-241, pt. 3, at 6 (1985)).

143 Id. (citing H.R. REP. No. 99-453, at 476 (1985) (Conf. Rep.)).

144 Id. (quoting Reid v. Indianapolis Osteopathic Med. Hosp., Inc., 709 F. Supp. 853, 855

(S.D. Ind. 1989)). 
ages that could be recovered under EMTALA through the incorporation clause of $\S 1395 \mathrm{dd}(\mathrm{d})(2)(\mathrm{A}) .^{145}$

In addition, the Fourth Circuit disagreed with the district court's views on the goals of EMTALA and the Virginia malpractice statute. EMTALA's preemption provision states: "The provisions of this section do not preempt any State or local law requirement, except to the extent that the requirement directly conflicts with a requirement of this section." ${ }^{146}$ The district court implicitly concluded that the state damage cap was preempted under $\S 1395 \mathrm{dd}(\mathrm{f})$ by finding that EMTALA's objectives of compensation and deterrence conflicted with the Virginia statute's goal of promoting insurance availability and affordability. ${ }^{147}$ However, the Fourth Circuit disagreed with this conclusion and reasoned that EMTALA and the state damage cap are not necessarily mutually exclusive simply because the overall purpose of EMTALA differs from the limited purpose of the malpractice damage cap. ${ }^{148}$

When enacting any legislation, including EMTALA, Congress must balance a number of conflicting concerns. ${ }^{149}$ As the United States Supreme Court has observed,

$[N]$ legislation pursues its purposes at all costs. Deciding what competing values will or will not be sacrificed to the achievement of a particular objective is the very essence of legislative choice-and it frustrates rather than effectuates legislative intent simplistically to assume that whatever furthers the statute's primary objective must be the law. ${ }^{150}$

Thus, the Fourth Circuit reasoned that EMTALA's damages provision ${ }^{151}$ was Congress's attempt to balance the deterrence and compensatory goals of EMTALA with deference to the ability of states to determine what damages are appropriate in order to avoid sacrificing either value completely. ${ }^{152}$

In addition, according to the Fourth Circuit, "the appropriate inquiry for purposes of determining whether EMTALA preempted Virginia's statute under

145 Id. at 862-63 (quoting Reid, 709 F. Supp. at 855); see supra note 106 and infra note 181 (discussing Reid in further detail); see also Lee v. Alleghany Reg'l Hosp. Corp., 778 F. Supp. 900, 903-04 (W.D. Va. 1991) (following the reasoning of Reid to hold that an EMTALA plaintiff's recovery was limited by Virginia's cap on medical malpractice damages).

14642 U.S.C. $§ 1395 \mathrm{dd}(\mathrm{f})$ (2000); Power II, supra note 60, at 863 n.10.

147 Power II, supra note 60, at 863 (citing Power I, supra note 59, at 1389).

148 Id.

149 Id.

150 Rodriguez v. United States, 480 U.S. 522, 525-26 (1987), quoted in Power II, supra note 60 , at 863 .

$151 \S 1395 \mathrm{dd}(\mathrm{d})(2)(\mathrm{A})$.

152 Power II, supra note 60, at 863 . 
$\S 1395 \mathrm{dd}(\mathrm{f})$ would be whether the actual cap of one million dollars 'directly conflicts' with the goals of EMTALA."153 The court found that there was no direct conflict. ${ }^{154}$ Finally, even if there was a direct conflict, the court concluded that a preemption analysis was not necessary because the federal statute, EMTALA in this case, expressly incorporates state law in its damages provision. ${ }^{155}$

In conclusion, the court deemed Ms. Power's EMTALA claim a malpractice claim under the Virginia Medical Malpractice Act for the purpose of applying the damage cap, despite the fact that it did not allege a breach of the prevailing professional standard of care generally associated with a malpractice claim. ${ }^{156}$ Because the EMTALA claim fell within the coverage of the malpractice cap, the court limited the plaintiff's recoverable damages to one million dollars. ${ }^{157}$ Ultimately, the Fourth Circuit's decision to reverse the district court and find that state damage caps applied to the EMTALA claim avoided multi-

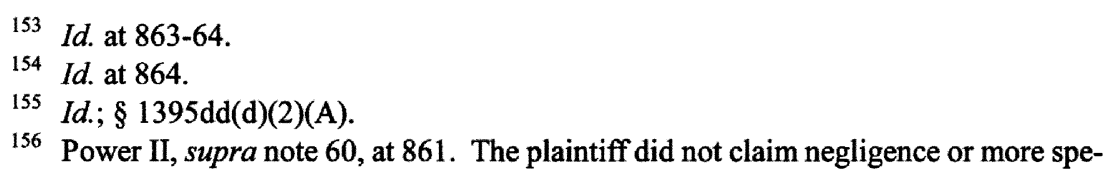
cifically, a breach of duty on the part of the hospital; rather, she alleged the hospital violated several EMTALA requirements. Power I, supra note 59, at 1387 n.6; see supra note 62 and accompanying text. EMTALA requirements providing for civil enforcement by an individual are imposed under a strict liability standard, not negligence. Power I, supra note 59, at $1387 \mathrm{n} .6$ (citing Abercrombie v. Osteopathic Hosp. Founders Ass'n, 950 F.2d 676, 681 (10th Cir. 1991)). In order for the plaintiff to prove that the hospital did not provide her with an appropriate medical screening, she must show that the screening was not as thorough or careful as that which the hospital would have provided to any other patient. Id. This may be established through proof of a failure to adhere to the hospital's standard protocols, or, where no such standard protocols exist, proof of a failure to meet the standard of care to which the hospital adheres. Id. In this second instance, the district court in Power I recognized that the line between malpractice and an EMTALA violation "blurs somewhat." Id. Thus, it is possible for a violation to constitute both an EMTALA violation and medical malpractice (where one requirement under a standard for an appropriate medical screening is not met), or only medical malpractice (in an instance where all requirements under a certain standard are satisfied but the incorrect conclusion is made). Id.

157 Power II, supra note 60, at 861. The court also noted that its holding in Power II did not contradict its holdings in Brooks v. Maryland General Hospital, 996 F.2d 708 (4th Cir. 1993), and Baber v. Hospital Corp. of America, 977 F.2d 872 (4th Cir. 1992). Id. at 864 . In these cases the court concluded that EMTALA was not intended to displace state malpractice law and its purpose was not "to guarantee that all patients are properly diagnosed, or even to ensure that they receive adequate care." Id. Rather, the court emphasized its adherence to these holdings and agreed with the district court's view in Power I that there are "'sharp differences between a medical malpractice action and an EMTALA action,' and that ' $[t]$ hey are separate and distinct causes of action focused on different conduct and aimed at different goals." Id. (quoting Powers I, supra note 59, at 1390). Nevertheless, in order to interpret EMTALA's damages provision, analyzing whether an EMTALA claim would be deemed a malpractice claim under the applicable state law most closely follows Congress's direction that courts should look to state law to determine what damages are available in an EMTALA action. Id.; see H.R. REP. No. 99-453, at 476 (1985) (Conf. Rep.). 
ple adverse effects and negative policy implications. ${ }^{158}$ Its decision gave effect to the plain language of EMTALA's damages provision while not unduly burdening hospitals or jeopardizing the availability of health care in general. ${ }^{159}$

\section{Promoting ACCESSIBle, AfFordable, AND High QUAlity HeAlth CARE: KEY POLICY REASONS FOR APPLYING STATE MEDICAL MALPRACTICE DAMAGE CAPS TO EMTALA ClAIMS}

Courts agree that EMTALA is not technically considered a medical malpractice statute and therefore does not create a cause of action based on professional negligence or medical malpractice. ${ }^{160}$ EMTALA "is not a federal malpractice statute and it does not set a national emergency health care standard; claims of misdiagnosis or inadequate treatment are left to the state malpractice arena." ${ }^{\text {"161 }}$ EMTALA claims are not based on whether a hospital was negligent; rather, they are based on strict liability and are, therefore, distinguishable from state medical malpractice statutes in which the plaintiff typically must prove the traditional medical malpractice tort claim by showing the provider was negligent. ${ }^{162}$ EMTALA provisions were not intended to comprise a "Federal Medical Malpractice Act.",163

The very reasons for which courts have refused to construe EMTALA as creating a federal cause of action for medical malpractice, ${ }^{164}$ however, are the precise reasons why state damage caps should be applied to EMTALA claims in addition to state medical malpractice claims. Although it may seem counterintuitive to argue simultaneously that EMTALA is not a federal medical malpractice statute and that state damage caps should be applied to EMTALA claims, one must focus on the underlying principles and policy implications associated with construing EMTALA as distinct from state medical malpractice

158 See infra Part IV.

159 C. Celeste Creswell, Power v. Arlington Hospital Association: Extending COBRA's Striking Distance While Weakening the Power of Its Venom, 29 GA. L. REv. 1171, 1174 (1995).

160 Summers v. Baptist Med. Ctr. Arkadelphia, 91 F.3d 1132, 1137 (8th Cir. 1996).

161 Id.

162 See id. Medical malpractice claims, however, may also be based on intentional tort or strict liability theories. See, e.g., Anderson v. Prease, 445 A.2d 612 (D.C. 1982) (medical malpractice claim based on a theory of intentional infliction of emotional distress); Hoven v. Kelble, 256 N.W.2d 379 (Wis. 1977) (medical malpractice claim based on a theory of strict liability, although court ultimately refused to apply that theory).

163 Power I, supra note 59, at 1387 n.6 (allowing the plaintiff to bring a seemingly traditional malpractice action under EMTALA because plaintiff emphasized that she was not only misdiagnosed but was also inappropriately transferred to a different hospital).

164 Such reasons include the following: to prevent forum shopping and the expansion of avenues through which plaintiffs may bring medical malpractice suits and to protect health care providers from being exposed to even greater liability by being liable under both state and federal law for medical malpractice. 
laws as well as the legislative purpose and goals for enacting EMTALA in the first place.

It would be much too simplistic to conclude that because EMTALA is not considered a federal medical malpractice statute, damage caps applicable to state medical malpractice claims should not apply to claims brought under EMTALA. This would be inconsistent with not only the policy behind Congress's enactment of EMTALA, but also the policy considerations that have supported medical malpractice reform efforts in many states and the language of EMTALA that explicitly directs courts to look to state law in order to determine what damages are available. ${ }^{165}$ The negative policy implications of failing to incorporate damage caps on EMTALA claims are significant and would heavily impact health care providers and health care consumers alike by affecting the affordability, accessibility, and quality of health care in the United States. Furthermore, it would be a large step backward in the nationwide effort to improve state medical malpractice environments for health care providers.

\section{A. Incorporating Damage Caps Will Prevent Plaintiffs from Circumventing State Damage Caps by Bringing Their State Malpractice Claims in Fed- eral Court Under EMTALA}

Damage caps should be applied to EMTALA claims in order to prevent plaintiffs from manipulating their claims into patient dumping actions merely to circumvent the recovery caps under traditional state medical malpractice statutes. ${ }^{166}$ Applying damage caps to EMTALA claims that are actually based on malpractice-like conduct limits the plaintiff's potential monetary award, regardless of whether he or she files suit in federal court under the guise of EMTALA or in state court under the medical malpractice statute. This removes some of the incentive plaintiffs would have to manipulate a traditional malpractice claim into an EMTALA action simply to avoid the state damage caps, with the hope of recovering more than the cap allows. ${ }^{167}$

Moreover, framing a suit under EMTALA will allow a plaintiff to recover under strict liability, ${ }^{168}$ relieving the plaintiff of the burden of proving negligence, as is typically required with traditional malpractice suits. ${ }^{169}$ Lowering the burden of proof provides plaintiffs another incentive to file in federal court under EMTALA and likely renders it easier for plaintiffs to obtain a verdict in

165 See 42 U.S.C. $§ 1395 \mathrm{dd}(\mathrm{d})(2)($ A) (2000); H.R. REP. No. 99-453, at 476 (1985) (Conf. Rep.)

166 Arguably, the plaintiff engaged in this type of manipulation in Power I because the facts presented in the case did not clearly support an EMTALA claim, and it was questionable whether the plaintiff was actually dumped. Bardot, supra note 67, at 255, 260-61. For more discussion and analysis of Power I generally, see $i d$. at 255 .

167 See id.

168 Id. at $262 \mathrm{n} .108$.

169 Id. at 257 n. 77. 
their favor. ${ }^{170}$ Permitting plaintiffs to circumvent the traditional burden of proof requirements will also exacerbate the malpractice crisis occurring in this country, where malpractice insurance carriers will charge providers higher premiums either to safeguard against and cover the costs of potential future claims or to recoup the costs of defending past actions or paying out prior judgments. ${ }^{171}$ This increased cost will be passed along to patients, many of whom are frequently unable to afford health care in the first place. Individual consumers will be forced to absorb these costs to the detriment of the health care system. ${ }^{172}$

Finally, merely pleading theories of "non-negligence," such as EMTALA violations, should not allow plaintiffs to circumvent state medical malpractice statutes' damage caps. ${ }^{173}$ Not applying a state damage cap to EMTALA claims would provide plaintiffs with the opportunity to avoid such a state limitation simply because he or she chose to pursue a cause of action for both professional negligence and a violation of EMTALA. ${ }^{174}$ There is not a meaningful or legally sound reason, however, for allowing circumvention of state damage caps on those grounds. This would result in plaintiffs simply crafting their complaints in a way that implicates "non-negligence" or strict liability, the standard upon which EMTALA is typically based, so as to avoid application of a state damage cap. ${ }^{175}$ Moreover, there would be further claim manipulation and uncertainty as

170 Id.

171 See Richard E. Anderson, The Case for Legal Reform, in MEDICAL MALPRACTICE: A Physician's SourcebooK 208 (Richard E. Anderson ed., Humana Press 2004) [hereinafter Anderson, The Case for Legal Reform] ("Insurers must collect premium today to pay for the cost of claims in the future."). It is the insurance company's fiduciary responsibility to invest premium dollars carefully so that funds will be available to pay claims when needed. $I d$.

172 Bardot, supra note 67, at 262.

173 See Cal. Health Professionals Urge Court to Uphold MICRA Damage Limits 3-3 MEALEY'S MANAGED CARE LIABILITY REP. 12 (1999) (discussing Barris v. County of Los Angeles, 972 P.2d 966 (Cal. 1999)). In Barris, the plaintiff sued the county hospital, claiming that the hospital violated EMTALA by failing to stabilize the patient, her eighteen-month-old daughter, before transfer. Barris, 972 P.2d at 969. The California Supreme Court ultimately upheld the trial court's decision, stating the damages award was subject to the state's limit because it broadly applied to causes of action based on professional negligence. Id. at 974 . The court applied the approach often taken by federal courts by determining whether an EMTALA claim, if brought under state law, would constitute an "action for injury against a health care provider based on professional negligence." Id. According to the court, a failure-to-stabilize claim under EMTALA was necessarily based on professional negligence. Id. Furthermore, the "apparent intent of Congress was to balance the deterrence and compensation goals of EMTALA with deference to the ability of states to determine what limits are appropriate in personal injury actions against health care providers." Id. at 973.

174 Cal. Health Professionals Urge Court to Uphold MICRA Damage Limits, 3-3 MEALEY'S MANAGED CARE LIABILITY REP. 12 (1999).

175 Id. 
to whether the state damage cap would apply in cases where plaintiffs assert alternative legal theories to negligence, such as violations of EMTALA. ${ }^{176}$

\section{B. Incorporating Damage Caps Will Prevent Forum Shopping}

Another reason, related to the manipulation of claims, that damage caps should be applied to EMTALA claims is to prevent forum shopping. Decisions in which courts have found state damage caps are not incorporated by EMTALA simply serve to promote this practice, which courts have generally sought to discourage since Erie Railroad Co. v. Tompkins. ${ }^{177}$ Potentially, a plaintiff would have an incentive to file an EMTALA suit based on malpractice-type conduct in federal court because he or she would be able to avoid the state damage caps that would be applied in state court, even though state courts have traditionally heard such claims sounding in medical malpractice.

Plaintiffs could simply frame a claim, which seems to be a typical medical malpractice action, in a manner that suggests patient dumping or another violation of EMTALA, in order to fit within the EMTALA framework and evade the malpractice damage cap to potentially obtain a higher award. ${ }^{178}$ A plaintiff would then have several venue options and could choose either a federal or state court according to what is most favorable to his or her case in general, in addition to the greater possibility of receiving more money for damages. Filing the claim in federal court would obviously be the more desirable option for plaintiffs if they could avoid damage caps in that forum. Thus, plaintiffs would more often file in federal court, overloading federal dockets and quickly exhausting judicial resources on claims typically handled by state courts. In addition, if a plaintiff still filed in state court, the inapplicability of damage caps to EMTALA claims would discourage a defendant from removing to federal court, even when there was a compelling reason to do so, because of the risk of a higher verdict against him or her. Furthermore, this would conflict with the legislative purpose behind state medical malpractice statutes as well as the congressional purpose behind EMTALA to ease the liability crisis and to ensure access to health care. ${ }^{179}$

\section{Incorporating Damage Caps Furthers the Purposes of EMTALA and State Medical Malpractice Statutes}

In addition, limiting certain EMTALA claims with damage caps would further the goal of EMTALA to ensure access to health care, especially to indi-

176 Id.

177 Erie R.R. Co. v. Tompkins, 304 U.S. 64 (1938) (establishing the policies of avoiding forum shopping and different results depending on the forum in which the case is tried), cited in Bardot, supra note 67 , at 260 \& n.94.

178 Bardot, supra note 67, at 261.

179 Id. at 261-63. 
gent and uninsured patients. By keeping recoveries at certain levels, overall health care costs can remain low or at least relatively stable because providers will be subject to less liability, and as a result, medical malpractice insurance premiums will level off or possibly decrease. This is similar to the goals of many state medical malpractice statutes. ${ }^{180}$

Furthermore, at the time Congress drafted EMTALA, it was clearly aware of the increasing concern in some states that excessive damage awards were causing a medical malpractice crisis. ${ }^{181}$ In response to this crisis, many states had enacted limits on the amount of damages that could be recovered. ${ }^{182}$ Thus, through the incorporation clause of EMTALA, Congress likely wished to preserve those limits on damages. ${ }^{183}$

In addition, in the context of the underlying policies and purposes of EMTALA and state malpractice statutes, it would be consistent to apply state damage caps to EMTALA claims sounding in medical malpractice. Although the court in Power I asserted that the purposes of EMTALA and the Virginia statute were conflicting, this was an erroneous conclusion because their purposes can actually be considered complementary. ${ }^{184}$ Both the federal EMTALA statute and state malpractice statutes serve to ensure health care for all individuals, regardless of their ability to pay ${ }^{185}$ For example, at issue in Power, Virginia's malpractice statute served to combat rising premiums for medical malpractice insurance, which is directly related to the purpose of ensuring universal access to adequate medical care underlying EMTALA ${ }^{186}$ Failing to consider this would greatly undercut the availability of health care to all individuals because it would open up yet another floodgate of litigation and thus would place more liability on health care providers, ultimately contributing to the already surging medical liability crisis in America.

Also, applying a damage cap to EMTALA claims will encourage potential plaintiffs to consider whether the limited available damages justify the costs of litigation. ${ }^{187}$ This would help to prevent a flood of EMTALA claims, in addition to simply frivolous EMTALA claims. One of the primary causes of the medical malpractice crisis in many states is the rising cost of defending claims combined with the high frequency of claims. ${ }^{188}$ Both of these factors would be

180 See id.

181 See H.R. REP. No. 99-241, pt. 3, at 6 (1985), cited in Power II, supra note 60; Reid v. Indianapolis Osteopathic Med. Hosp., Inc., 709 F. Supp. 853, 855 (S.D. Ind. 1989) (holding that EMTALA incorporates state substantive limitation on the maximum amount recoverable from a health care provider because to hold otherwise would render the incorporation clause of $\S$ $1395 \mathrm{dd}(\mathrm{d})(2)(\mathrm{A})$ meaningless).

${ }_{182}$ Reid, 709 F. Supp. at 855.

183 Id.

184 Bardot, supra note 67, at 258.

185 Id.

186 Id.

187 Creswell, supra note 159, at 1172.

188 Anderson, Defending the Practice, supra note 11, at 1177. 
exacerbated if plaintiffs were given the option of pursuing an EMTALA claim without the damage cap limits. It is likely that plaintiffs will be more inclined to file such claims where there is a limitless potential for recoverable damages. Thus, even if the plaintiff does not prevail, the excessive litigation will still impose considerable costs on physicians who must defend such suits. ${ }^{189}$ This defense cost must then be calculated into the cost of insurance. ${ }^{190}$

Finally, if damage caps are not applied to EMTALA actions, physicians facing malpractice suits will potentially see higher payouts to plaintiffs under EMTALA, in comparison to state medical malpractice statutes that provide a damage cap. Also, more plaintiffs will frame their complaints under EMTALA because of the possibility of higher payouts, or, in the alternative, if they are simply unhappy with the recovery limits placed on malpractice claims by state law. ${ }^{191}$ Consequently, failing to apply damage caps to EMTALA claims will increase the frequency of claims filed against physicians.

\section{CONCLUSION}

Because of the ambiguity in EMTALA's damages provision, courts have gone in both directions on whether state damage caps shall apply to EMTALA claims. However, the majority of courts have found that state damage caps are applicable to EMTALA claims. This has prevented forum shopping and the manipulation of malpractice-based claims into EMTALA claims in many jurisdictions. In addition, this majority position is consistent with the underlying policies and purpose of EMTALA and state medical malpractice statutes: To ensure adequate access to and quality of health care to all in the United States by limiting the liability physicians face in their practices, which in turn results in lower malpractice insurance premiums for physicians and lower medical costs for consumers.

By controlling the cost of insurance, physicians will not have to pass on as much of the cost of expensive insurance to their patients, making health care more accessible to patients, regardless of their financial status. In addition, the practice of defensive medicine will decrease with the diminished fear of being sued and facing excessive or unlimited jury verdicts. Finally, physicians will be more satisfied with the practice of medicine and will be less likely to relocate or stop practicing, both of which could disrupt the continuity of care. ${ }^{192}$ Ultimately, this will result in higher quality health care, preserve access to treat-

189 Id. at 1174.

190 Id. In the United States, the average cost of defending one lawsuit is $\$ 22,967$, id., and if a case goes through a jury trial before a verdict for the defendant, it can cost over $\$ 85,000$. Anderson, Effective Legal Reform, supra note 11, at 345-46. The total cost of medical malpractice litigation in the United States now exceeds twenty-four billion dollars each year and continues to increase. Id. at 347 .

191 Bardot, supra note 67, at 262.

192 Anderson, Effective Legal Reform, supra note 11, at 353. 
ment, and promote a stable insurance market. ${ }^{193}$ In contrast, the likely primary effect, although probably unintended, of not applying state damage caps to EMTALA claims, which could also be framed as malpractice claims, is that potential plaintiffs will be permitted to bypass the state damage cap simply by framing a seemingly malpractice-based claim as an EMTALA claim. The amount of a possible recovery would be limitless.

While this seems to be a broad interpretation of EMTALA's damages provision, such a reading is necessary to effectuate the plain language of the provision and the policies underlying both EMTALA and state medical malpractice statutes. A narrow reading that does not incorporate state damage caps would have an adverse impact on both the federal and state legislatures' primary objective to promote high quality, accessible, and affordable health care. Thus, the incorporation of state damage caps into EMTALA is beneficial at the local level for medical liability and general tort reform, as well as at the national federal level.

In addition to the policy arguments, however, it should be considered that many courts base their broad interpretations and incorporation on the plain language of EMTALA, aside from or in addition to the policy implications. ${ }^{194}$ Therefore, if incorporation of state damage caps is in fact determined primarily by the plain language of EMTALA's damages provision in future decisions, narrowing the scope of EMTALA's damages provision or modifying the application of state malpractice statutes may have to be left to Congress or state legislatures. ${ }^{195}$

In conclusion, it is imperative that courts keep in mind the probable policy implications and potential adverse effects on access to and quality of health care when interpreting the damages provision of EMTALA and its incorporation of state malpractice damage caps. By following the majority approach to incorporate such damage caps, courts can avoid possible adverse effects on health care and simultaneously promote progress in tort reform generally, as well as progress in the context of medical malpractice liability. Ultimately, such an approach will be beneficial to health care consumers and will serve to diminish the crisis occurring in the area of medical malpractice liability by decreasing and controlling malpractice insurance costs, fostering patient access to medical treatment, and promoting a higher quality of health care in America.

193 Id. at 354.

194 See Smith v. Botsford Gen. Hosp., 419 F.3d 513, 517 (6th Cir. 2005), cert. denied, 126 S. Ct. 1912 (2006) (mem.); see also discussion supra Part III.B.1.

${ }^{195}$ See Gonzalez v. Fairfax Hosp. Sys. Inc., 389 S.E.2d 458, 460 (Va. 1990); see also supra text accompanying notes 122-25. 
